\title{
Stock Market Reaction to Impairment Announcement of Listed Manufacturing Companies in Sri Lanka
}

Sooriyakumaran Logeswary ${ }^{1 *}$ and Velnampy Thirunavukkarasu ${ }^{2}$

${ }^{1}$ Department of Accountancy, Advanced Technical Institute, Jaffna, Sri Lanka

${ }^{2}$ Faculty of Management, Studies and Commerce, University of Jaffna, Sri Lanka

\begin{abstract}
This study investigates the reaction of market and efficiency of market to announcement of impairment loss write down in Colombo Stock Exchange (CSE) from 2008 to 2014. This research is identified fifty-eight events of twenty listed manufacturing companies in CSE. The existent study used the standard event study approach to find the results. The hypotheses of operational were framed and results discovered that $55 \%$ of Average Abnormal Return (AAR) are positively and $45 \%$ of AARs are negatively on the occasion day "0" (event day). The results reveal negative AARs of $-0.37 \%$ and impact of negative significant on Share Price (SP) $(t=-1.6682)$ at $10 \%$ level which incurred on the impairment loss announcement date. These results shows that impairment loss writes down events indicate significant negative information to the CSE. End of the windows period abnormal returns are gained by market as positive return of CAAR of $9.15 \%$ during the windows period of 61 days. It reveals that CSE has not supported to the semi-strong form market efficiency which is run on publicly available information on CSE. Study focused that the CSE was not semi-strong efficient market. The outcome of the research will help to identify the market efficiency of CSE and do the necessary action by the Sri Lankan government and CSE to protect the investors and support to the economic growth of the country.
\end{abstract}

Keywords: Colombo stock exchange; Impairment of non-current assets; Impairment loss; Semi-strong form market and share prices

\section{Introduction}

The general purpose of financial reporting is to provide financial information about the reporting entity that is useful to present and potential investors, lenders and other creditors in making decisions about providing resources to the organization. Those decisions involve buying, selling or holding equity and debt instruments, and providing or settling loans and other forms of credit [1].

The reaction of share prices in accounting information has long been a significant topic among companies and investors. The information of prices fully reflect in the market is called efficient market. The consequence of an efficient market is that no return of excess can be made from this information, for the reason that present prices already reveal the information. Though, return of excess (if any) should not be statistically significant from zero. Efficiency of the market depends on the ability of dealers to dedicate their resources and time to collect and circulate the information.

The factors that contribute to return of abnormal also can assistance the companies to realize the motivating forces behind its performance of share market after the declaration, as it is a key indicator of investors' trust in the company.

All the countries, the market of capital is a significant frame in participating economic development. Traditionally it has been viewed as an indicator or predictor of the economy. Many believe that declining in share prices show the signals of slowdown of the economy, at the same time an increasing in stock prices is the evidence of growth of the country [2]. Share prices are determined on the basis of the expected cash flow to be received from a share and the risk involved. Investors' securities use all the information in determining the share prices. Therefore, information is the important factor for the determination of the share prices and significant problem of the efficient capital market [3].

Fox and Opong [4] defined that efficient market was the one, where the [5] argued that more efficient markets attracted to more investors, which paved the way to increased market liquidity. In Sri Lanka Colombo Stock Exchange (CSE) plays a major role in contributing much towards economic development. During the peace process situation functions of CSE was an emerging trend in Sri Lankan economy. The peace process gave comparatively steady political situation, inviting more foreign relief, low interest rate situation, enhanced economic basics and the improved the profitability of listed companies which had a positive effect on the performance of the Sri Lankan share market.

The several numbers of research in the finance sector gave the effect on market efficiency. These research studies are called as 'event studies'. Originally the event studies were commenced to test whether markets were efficient or not, in specific, how rapid the information was integrated in share price. Fama [6] mentioned that it was a matter of concern that the experience of firms announcing impairment of non-current asset lead to declining in their stock prices on an average supporting semi-strong form Efficient Market Hypothesis (EMH).

This research is to empirically investigate the announcement of impairment of non-current assets impact on stock prices of 37 listed manufacturing companies which were listed in Colombo stock Exchange (CSE) from 2008 to 2014. In this research, researchers analyzed the decisions of investors by evaluating the changes in the share prices during the event period. Investors have to concentrate on efficiency of market, because share price changes affect their wealth.

*Corresponding author: Sooriyakumaran Logeswary, Department of Accountancy, Advanced Technical Institute, Jaffna, Sri Lanka, Tel: 0771727837; E-mail: I.sooriyakumaran@gmail.com

Received December 10, 2018; Accepted December 28, 2018; Published January 04, 2019

Citation: Logeswary S, Thirunavukkarasu V (2019) Stock Market Reaction to Impairment Announcement of Listed Manufacturing Companies in Sri Lanka. J Account Mark 7: 307. doi: 10.4172/2168-9601.1000307

Copyright: (C) 2019 Logeswary S, et al. This is an open-access article distributed under the terms of the Creative Commons Attribution License, which permits unrestricted use, distribution, and reproduction in any medium, provided the original author and source are credited. 
Usually, inefficiency of share market will affect the consumption and spending of investment of the country, and finally it will impact the whole performance of the economy.

This research contributes to the body of work that attempt to explain how publicly accessible data on financial statements interpret into organization value. How the Sri Lankan share market react for this information? Therefore, this research delivers knowledge of correlations among numbers of accounting and value of organization. Furthermore, this research tries to offers empirical evidence, how efficiently professional analyst of financial and prospect investors use the essential signals while making their investment choices.

Therefore, this research tries to evaluate the impairment of noncurrent assets and its impact on share prices of the listed manufacturing companies in Sri Lanka.

\section{Statement of Problem}

The contents of events information and its dissemination govern the efficiency of the capital market. That is how quickly and correctly share prices reflected on this information. Many research studies have been accompanied to test the efficiency of the capital market with respect to content of events information in developed countries. Announcement of impairment of non-current assets influenced the share price of the firm had been well examined in the developed countries. Ramesh [7] pointed out that the research relevant to this area was low in the developing countries. With the evolution of accounting standards, more and more researchers have focused on the market reaction of write-downs announcement of assets. In this study, we have selected the application of LKAS 36 which is newly considered in Sri Lanka, while it has already been considered by the researchers in developed countries.

From the empirical evidence Hirschey and Richardson [8] concluded that shareholders initially showed under reaction to write down of goodwill declarations and they became aware of the possibilities for further losses in the post declaration period. Strong and Meyer [9] provided supporting evidence to have a positive effect on stock prices in that assets write downs. In the same way, Francis [10] found that the market reacts positively on the announcement of reformation changes. Alternatively, managers may write down the assets even if they have negative information about the future of the organisation. Frantz [11] argued that taking a big bath in the current period makes it more likely for earnings and managerial reward to be increased in the future. On this scenario, asset write-down information is deafening, which describes why the market may not show any reactions as reported by Zucca and Campbell [12] or respond adversely as documented by Elliot and Shaw [13]. Hirchey and Richardson [8] also explained the underreaction of stockholders to asset write off. The researchers identified that announcement of impairment of assets write off has an adverse effect on company share price in the value of $-2.94 \%$ to -3.52 .

From the above argument about the inter-relationship among the impairment loss and share price, they have positive, negative and no relationship among them and announcement of impairment loss written down impact on share prices in both ways and market efficiency also reflected for the announcement.

Therefore, the researchers have identified the under mentioned problem statement in the announcement of impairment of noncurrent assets and reaction of share prices of listed manufacturing companies in CSE.
The problem statement is as follows "Do the Impairment of noncurrent assets announcements impact to share market?"

This study is undertaken to explore the answers to the following research questions (RQ):

RQ 1: Do announcements of Impairment Loss (IL) have impact on market efficiency of the stocks traded on CSE?

RQ2: Does Colombo Stock Exchange (CSE) consistent with the semi-strong form efficient market?

The objectives of this research are:-

The key objective of the research is to inspect the impact of impairment of non-current assets on share price of listed manufacturing companies in CSE.

The following Sub-objective has been considered.

- To find out the efficiency of the Sri Lankan share market during the period of impairment loss announcements.

\section{Literature Review}

When we evaluate the role of impaired assets on quoted share prices in an efficient market, the share price is supposed to reflect all obtainable information about the appropriate organization. In this research researchers particularly considered the market reaction of respective of the accounting treatment of identifying current value diminutions in the assets of the entity and such declines would have the effect of reducing the share price. Erlend [14] mentioned that on the assumption of impartial accounting of impairment, it would presume that write-downs to be adversely correlated with prior share performance. The performance of the company's share is deflated by the firms' performance. Hence efficient capital market is expected to negatively relate for the impairment decision.

According to research findings of empirical researchers $[13,9,15,12]$, they concluded that when companies declared the impairment of asset, it would cause to declining their share prices. Greater value of impairment of asset acknowledged the larger loss of the share price on the day of the announcement. Though, the experiential study conducted by Zucca and Campbell [12] showed that no adverse market effects happened when entities announced impairment of assets. This means, the market realized the purpose of enterprise recording of impairment of assets as earnings management, not impairments to enterprises' real value of asset. Moreover, enterprise recording of impairment of asset had undesirable effects on the market. Riedl [16] carry out the comparison of the correlations among the motivation behind reporting asset impairment and economic factors before and after the announcement of SFAS No.144. Based on the examination outcomes, the correlation of after the announcement of impairment of assets was lower than before the announcement made. Lin and Liao mentioned that the electronic industry suffered larger adverse effects from impairment of asset compared to the shorter product life of electronic products with non-electronic industry. The experiential results of the research carried out by Chen [17] revealed that the losses arising from impairment of asset announced by entities actually mirrored on the share prices in the same period. The research outcomes recommended that a significant negative correlation occurred between impairment of asset and evaluation of entities. On the other hand, the existence of indolent assets did not reasonable the effects between impairment of asset and evaluation of companies.

Based on the above studies, foreign literatures have mixed views 
Citation: Logeswary S, Thirunavukkarasu V (2019) Stock Market Reaction to Impairment Announcement of Listed Manufacturing Companies in Sri Lanka. J Account Mark 7: 307. doi: 10.4172/2168-9601.1000307

Page 3 of 8

on the effects of companies' reporting of impairment of asset on the market reaction.

We have moderated the following hypotheses in our research.

H 1: Announcement of Impairment loss has significant impacts on the share prices of the shares traded on CSE.

H 2: Colombo Stock Exchange (CSE) is consistent with the semi-strong form efficient market.

The research question is how the impairment loss of non-current assets, effects on the company's share price?

\section{Methodology}

The research calculates daily return for individual shares on the basis of daily closing share prices. Under the situation where the price for the non-traded on a given date, the following merchandised price is considered as the price for the non-trading date. A recognized statistical package for social sciences (SPSS) 20.0 versions and M.S. Excel is used in order to analyze the data. The researchers have applied a purposeful selection of the sample, which encompasses 259 financial statements included in the stock exchange index. The financial statements concern financial year 2007-2014. Thus, the final sample contains 62 'events' of impairment loss announcement. For every announcement, the daily share returns were measured for a period of 181 days surrounding the 'event'. These 181 days are divided into two groups from $\mathrm{t}=-151$ to $\mathrm{t}=$ -30 , the estimation period and $t=-30$ to $t=+30$, the event period.

Primary data and information were gathered from CSE which is identified that all information is correct and realistic. Confirmation processes involved initial discussion with expert researchers. Therefore, researchers are highly satisfied with the data.

The manufacturing companies which were listed on the Colombo Stock Exchange (CSE), Sri Lanka were taken for the scope of the study. Thirty-seven companies are listed under manufacturing sectors. After the analyzing all the thirty-seven companies, it was found that twentytwo companies only recorded the write down amount of impairment loss of non-current assets. Out of the above 22 companies Alumax PLC and Swadeshi PLC is excluded from the sample due to the unavailable of share prices. Hence 20 companies are selected for the research (Table 1).

The IL write down have been mostly done by Ceylon Grain Elevators PLC, Dipped Products PLC in their financial statements. During the research period the IL write down has been done only one time of the Acme Printing, Packaging PLC, Blue Diamonds, Jewellery PLC, Kelani Cables PLC, Print Care, PLC, Regnis PLC and Royal Ceramics Lanka PLC in their financial statements to satisfy the company act and solvency test.

\section{Results and Discussion}

\section{Impairment loss announcements and share prices-empirical results}

IL is independent variable and SP is the dependent variable. Here event study of market model is used to analyze the variables. Researchers present information of descriptive statistics for the share market reaction to IL write down announcement event of AARs. The Maximum, minimum, median and skewness were measured for 58 events related to the IL announcement in CSE over the period of 7 years. They are described in Table 2.

NILA - Number of Impairment Loss Announcement

Table 2 describes the AAR around the declaration date of the IL.

\begin{tabular}{|c|c|}
\hline Company Name & Number of Write down Announcements \\
\hline Acme Printing, Packaging PLC & 1 \\
\hline Blue Diamonds, Jewellery PLC & 1 \\
\hline Bogala Graphite Lanka PLC & 5 \\
\hline Central Industries PLC & 5 \\
\hline Ceylon Grain Elevators PLC & 6 \\
\hline Dankotuwa Porcelain PLC & 3 \\
\hline Dipped Products PLC & 6 \\
\hline Kelani Cables PLC & 1 \\
\hline Kelani Tires PLC & 5 \\
\hline Lanka Tiles PLC & 2 \\
\hline Lanka Walltiles PLC & 3 \\
\hline Laxapana Batteries PLC & 2 \\
\hline Orient Garments PLC & 3 \\
\hline Print Care, PLC & 1 \\
\hline Regnis PLC & 1 \\
\hline Richard Pieris Exports PLC & 3 \\
\hline Royal Ceramics Lanka PLC & 1 \\
\hline Sierra Cables PLC & 3 \\
\hline Singer Industries PLC & 4 \\
\hline Tokyo Cement Company PLC & 2 \\
\hline & \\
\hline
\end{tabular}

Table 1: Selected companies and number of write down announcements.

\begin{tabular}{|c|c|c|c|c|c|c|}
\hline Sample companies & $\mathbf{N}$ & Minimum & Maximum & Mean & Skewness & NILA \\
\hline $\begin{array}{c}\text { Laxapana Batteries } \\
\text { PLC }\end{array}$ & 58 & -.0417 & .0328 & -.002108 & -.126 & 2 \\
\hline $\begin{array}{l}\text { Tokyo Cement } \\
\text { Company PLC }\end{array}$ & 58 & -.0420 & .0615 & -.000497 & .451 & 2 \\
\hline $\begin{array}{c}\text { Acme } \\
\text { PrintingPackaging } \\
\text { PLC }\end{array}$ & 58 & -.0203 & .0216 & -.000464 & -.260 & 1 \\
\hline Sierra Cables PLC & 58 & -.0419 & .0652 & -.000405 & .818 & 3 \\
\hline $\begin{array}{l}\text { Blue Diamonds } \\
\text { Jewellery PLC }\end{array}$ & 58 & -.0525 & .1566 & -.000339 & 1.742 & 1 \\
\hline $\begin{array}{l}\text { Royal Ceramics } \\
\text { Lanka PLC }\end{array}$ & 58 & -.0345 & .0340 & -.000258 & -.238 & 1 \\
\hline $\begin{array}{c}\text { Dipped Products } \\
\text { PLC }\end{array}$ & 58 & -.0221 & .0158 & -.000076 & -.133 & 6 \\
\hline Regnis PLC & 58 & -.0330 & .0511 & .000487 & .874 & 1 \\
\hline $\begin{array}{l}\text { Richard Pieris } \\
\text { Exports PLC }\end{array}$ & 58 & -.0539 & .0508 & .000698 & .025 & 3 \\
\hline $\begin{array}{c}\text { Central Industries } \\
\text { PLC }\end{array}$ & 58 & -.0351 & .0387 & .000756 & .100 & 5 \\
\hline Kelani Cables PLC & 58 & -.0087 & .0259 & .000896 & 2.474 & 1 \\
\hline $\begin{array}{c}\text { Singer Industries } \\
\text { PLC }\end{array}$ & 58 & -.0586 & .0546 & .001042 & -.168 & 4 \\
\hline Kelani Tyres PLC & 58 & -.0198 & .0261 & .001059 & .053 & 5 \\
\hline Lanka Tiles PLC & 58 & -.0555 & .0644 & .001569 & .427 & 2 \\
\hline Print Care PLC & 58 & -.1946 & .1919 & .001918 & .216 & 1 \\
\hline $\begin{array}{c}\text { Lanka Walltiles } \\
\text { PLC }\end{array}$ & 58 & -.0348 & .0282 & .002435 & -.094 & 3 \\
\hline $\begin{array}{c}\text { Dankotuwa } \\
\text { Porcelain PLC }\end{array}$ & 58 & -.0355 & .0445 & .002573 & .255 & 3 \\
\hline $\begin{array}{c}\text { Orient Garments } \\
\text { PLC }\end{array}$ & 58 & -.0228 & .0888 & .003256 & 1.982 & 3 \\
\hline $\begin{array}{l}\text { Ceylon Grain } \\
\text { Elevators PLC }\end{array}$ & 58 & -.0298 & .0376 & .004757 & .332 & 6 \\
\hline $\begin{array}{c}\text { Bogala Graphite } \\
\text { Lanka PLC }\end{array}$ & 58 & -.0417 & 1.2108 & .020916 & 7.657 & 5 \\
\hline
\end{tabular}

Table 2: Descriptive and statistical of average abnormal return (AAR) for manufacturing sector.

Day zero matches to the date of the declaration and the return of days 30 corresponds to the return perceived during the 30 trading days 
of Impairment Loss Announcement (NILA) events for each sample company in this study. Sample companies refer to listed manufacturing companies in CSE which announced the IL amount in their financial statements and released the news.

The table has ascended according to the value of AAR mean. Laxapana Batteries PLC has the lowest mean of -0.002108 and Bogala Graphite Lanka PLC has the highest mean of 0.020916 from the sample within the research period. The returns for twenty companies' shares indicated negative and positive skewness, a signal that the return distributions of the stocks in our sample have a 29\% (NILA -17) of being negative. The negative skewed entities would be more discouraging for shareholders to participate in future. At the same time, 71\% (NILA41) of events shows the positive skewness. The companies which showed the positive skewed would be more inspiring for financiers to invest in forthcoming. Here during the research period most of loss making companies shows the positive skewness. Like Blue Diamonds Jewellery-1.742, Bogala Graphite Lanka PLC - 7.657. It is ensuring that relevant of accounting information and maintains the fair value of the enterprises will raise the encouragement of investment.

The Table 3 shows that the impairment announcement may be informative content of a mix of both negative and positive reactions. In the year $200867 \%$ of the events have positive returns while $33 \%$ reported as a negative reaction. But in the year 2009 and 2010, there were $57 \%$ positive reactions and negative reaction was $43 \%$. In 2011 there was a negative reaction as $56 \%$, but on the other hand $44 \%$ of positive reactions. The negative reaction continued to increase in the 2013 at $80 \%$ and $20 \%$ positive reactions to the events have observed during this year.

Identify number of positive trend and negative trend of abnormal returns (AR) for the study on the IL announcement date (event day = 0 ) are presented in Table 4. It displays that how the market reacts to the news of the IL announcement on the event day over the study period.

The trend of the abnormal returns on the announcement of impairment date is presented in Table 4 for the fifty-eight events. As shown in the table, $45 \%$ of the events have negative AARs, while $55 \%$ of the events have positive AARs on the announcement of impairment date. This discloses that positive AARs are more than the negative AARs on the announcement of impairment date. Hence, the whole market response is positive at the same time negative reaction also considerable. The announcement of impairment may be an informational content in the overall study period.

It is found that from the Table 5 the direction of abnormal of the window period, which shows the abnormal returns are positive than negative returns in all years. In year 2008 there are $78 \%$ of abnormal returns are positive $22 \%$ of the abnormal returns are negative. In the year $200955 \%$ of abnormal returns are positive while $45 \%$ of abnormal returns are negative. In year 2010 the situation is changing as positive abnormal returns decrease and negative abnormal returns increased as $24 \%$ and $76 \%$ respectively. But it is changed almost same as previous with the positive direction of AR is $58 \%$ in the year 2012. But in the year 2013 the positive direction of AR is $45 \%$ and the negative direction is $55 \%$ like 2010.

In addition, the Table 6 shows the number of positive direction and negative direction of abnormal returns $(\mathrm{AR})$ of the window period $(-30$ to +30 ) for total observation.

The above Table 6 shows total observation of the Abnormal Returns (ARs) direction of the window period of whole sample and the all events are $3538.50 .59 \%$ of abnormal returns are positive while $49.4 \%$ of abnormal returns are in a negative direction. So impairment of noncurrent assets announcement impact on the CSE $49 \%$ negatively and $51 \%$ positively.

When researchers measure the ARs into AARs (Day " 0 "= -1.6682) which mention the more support signals as negative and $10 \%$ considerable significant amount. Few sample entities ARs have compensated larger or less adverse signals of $10 \%$ in $t$ value of other sample companies.

\begin{tabular}{|c|c|c|c|c|c|c|c|c|c|c|c|c|c|c|}
\hline \multirow{2}{*}{ Direction } & \multicolumn{2}{|c|}{2008} & \multicolumn{2}{|c|}{2009} & \multicolumn{2}{|c|}{2010} & \multicolumn{2}{|c|}{2011} & \multicolumn{2}{|c|}{2012} & \multicolumn{2}{|c|}{2013} & \multicolumn{2}{|c|}{2014} \\
\hline & No & $\%$ & No & $\%$ & No & $\%$ & No & $\%$ & No & $\%$ & No & $\%$ & No & $\%$ \\
\hline Positive & 6 & 67 & 4 & 57 & 4 & 57 & 4 & 44 & 8 & 89 & 2 & 20 & 4 & 57 \\
\hline Negative & 3 & 33 & 3 & 43 & 3 & 43 & 5 & 56 & 1 & 11 & 8 & 80 & 3 & 43 \\
\hline Total & 9 & 100 & 7 & 100 & 7 & 100 & 9 & 100 & 9 & 100 & 10 & 100 & 7 & 100 \\
\hline
\end{tabular}

Table 3: Direction of average abnormal returns (AAR \%) on day 0 of overall sample.

\begin{tabular}{|c|c|c|}
\hline Trend & Number of events & Percentage of events \\
\hline Positive & 32 & $55 \%$ \\
\hline Negative & 26 & $45 \%$ \\
\hline Total events & 58 & $100 \%$ \\
\hline
\end{tabular}

Table 4: Trend of AARs on day 0 .

\begin{tabular}{|c|c|c|c|c|c|c|c|c|c|c|c|c|c|c|}
\hline \multirow{2}{*}{ Direction } & \multicolumn{2}{|c|}{2008} & \multicolumn{2}{|c|}{2009} & \multicolumn{2}{|c|}{2010} & \multicolumn{2}{|c|}{2011} & \multicolumn{2}{|c|}{2012} & \multicolumn{2}{|c|}{2013} & \multicolumn{2}{|c|}{2014} \\
\hline & No. & $\%$ & No. & $\%$ & No. & $\%$ & No. & $\%$ & No. & $\%$ & No. & $\%$ & No. & $\%$ \\
\hline Positive & 426 & 78 & 235 & 55 & 103 & 24 & 199 & 36 & 317 & 58 & 277 & 45 & 233 & 55 \\
\hline Negative & 123 & 22 & 192 & 45 & 324 & 76 & 350 & 64 & 232 & 42 & 333 & 55 & 194 & 45 \\
\hline Total & 549 & 100 & 427 & 100 & 427 & 100 & 549 & 100 & 549 & 100 & 610 & 100 & 427 & 100 \\
\hline
\end{tabular}

Table 5: Direction of average abnormal returns (AARs) of the window period of total observation for the study period of 2007 to 2014 .

\begin{tabular}{|c|c|c|}
\hline Direction & Number & Percentage \\
\hline Positive & 1790 & $50.59 \%$ \\
\hline Negative & 1748 & $49.4 \%$ \\
\hline Total & 3538 & 100 \\
\hline
\end{tabular}

Table 6: ARs direction of the window period. 
Citation: Logeswary S, Thirunavukkarasu V (2019) Stock Market Reaction to Impairment Announcement of Listed Manufacturing Companies in Sri Lanka. J Account Mark 7: 307. doi: 10.4172/2168-9601.1000307

Page 5 of 8

If the event is statistically significant that might be due to leakage of the board of directors' decision of entering the loss of assets impairment in the financial statements. The fact that the information of impairment loss writes down, leads to insiders' trading activities. However, no theory can be presented on why leakage should occur on these specific dates.

In Table 7 the AAR is displaying that the average deviance of the returns of the share from their usual returns with the market index. At the same time CAAR means the cumulative deviations of the shares'

\begin{tabular}{|c|c|c|c|c|}
\hline \multirow{2}{*}{$\begin{array}{l}\text { Day relative to IL } \\
\text { announcement }\end{array}$} & \multicolumn{4}{|c|}{ Standard Deviation 0.007355} \\
\hline & AAR\% & CAARs $\%$ & T(AARs) & $-/+$ Sign \\
\hline-30 & $1.24 \%$ & $1.24 \%$ & $* * \star 5.5910$ & 22,36 \\
\hline-29 & $-0.06 \%$ & $1.18 \%$ & -0.2818 & 33,25 \\
\hline-28 & $-1.06 \%$ & $0.12 \%$ & ${ }^{* * *}-4.7794$ & 31,27 \\
\hline-27 & $-0.01 \%$ & $0.10 \%$ & -0.0640 & 29,29 \\
\hline-26 & $-0.79 \%$ & $-0.69 \%$ & ${ }^{* * *}-3.5742$ & 42,16 \\
\hline-25 & $0.47 \%$ & $-0.22 \%$ & **2.1026 & 26,32 \\
\hline-24 & $-0.51 \%$ & $-0.73 \%$ & **-2.2927 & 24,34 \\
\hline-23 & $0.07 \%$ & $-0.67 \%$ & 0.2947 & 27,31 \\
\hline-22 & $-0.64 \%$ & $-1.31 \%$ & ${ }^{* * *}-2.8910$ & 36,22 \\
\hline-21 & $-0.29 \%$ & $-1.60 \%$ & -1.3137 & 26,32 \\
\hline-20 & $-0.09 \%$ & $-1.69 \%$ & -0.4269 & 29,29 \\
\hline-19 & $-0.03 \%$ & $-1.73 \%$ & -0.1525 & 28,30 \\
\hline-18 & $0.16 \%$ & $-1.56 \%$ & 0.7402 & 25,33 \\
\hline-17 & $-1.21 \%$ & $-2.77 \%$ & $* * *-5.4346$ & 32,26 \\
\hline-16 & $-1.02 \%$ & $-3.79 \%$ & ${ }^{* * *}-4.5991$ & 26,32 \\
\hline-15 & $-0.64 \%$ & $-4.43 \%$ & $* * *-2.8814$ & 30,28 \\
\hline-14 & $0.11 \%$ & $-4.32 \%$ & 0.4937 & 27,31 \\
\hline-13 & $0.00 \%$ & $-4.32 \%$ & -0.0065 & 32,26 \\
\hline-12 & $-0.05 \%$ & $-4.37 \%$ & -0.2110 & 37,21 \\
\hline-11 & $0.08 \%$ & $-4.29 \%$ & 0.3636 & 32,26 \\
\hline-10 & $0.07 \%$ & $-4.22 \%$ & 0.3040 & 20,38 \\
\hline-09 & $1.37 \%$ & $-2.86 \%$ & $* \star * 6.1513$ & 23,35 \\
\hline-08 & $0.17 \%$ & $-2.69 \%$ & 0.7671 & 33,25 \\
\hline-07 & $-0.27 \%$ & $-2.95 \%$ & -1.2082 & 28,30 \\
\hline-06 & $0.58 \%$ & $-2.37 \%$ & $\star * \star 2.6198$ & 29,29 \\
\hline-05 & $-0.10 \%$ & $-2.48 \%$ & -0.4688 & 23,35 \\
\hline-04 & $0.26 \%$ & $-2.22 \%$ & 1.1552 & 38,20 \\
\hline-03 & $0.40 \%$ & $-1.82 \%$ & *1.7968 & 27,31 \\
\hline-02 & $0.03 \%$ & $-1.79 \%$ & 0.1301 & 31,27 \\
\hline-01 & $0.48 \%$ & $-1.31 \%$ & **2.1688 & 25,33 \\
\hline 0 & $-0.37 \%$ & $-1.68 \%$ & *-1.6682 & 26,32 \\
\hline 01 & $0.69 \%$ & $-0.99 \%$ & ***3.1225 & 23,35 \\
\hline 02 & $3.97 \%$ & $2.98 \%$ & $* * * 17.8790$ & 28,30 \\
\hline 03 & $-1.05 \%$ & $1.93 \%$ & $* * *-4.7402$ & 34,24 \\
\hline 04 & $0.22 \%$ & $2.15 \%$ & 0.9935 & 30,28 \\
\hline 05 & $0.10 \%$ & $2.25 \%$ & 0.4678 & 26,32 \\
\hline 06 & $0.80 \%$ & $3.05 \%$ & ***3.6082 & 30,28 \\
\hline 07 & $-0.32 \%$ & $2.74 \%$ & -1.4257 & 28,30 \\
\hline 08 & $0.00 \%$ & $2.74 \%$ & -0.0010 & 24,34 \\
\hline 09 & $0.35 \%$ & $3.09 \%$ & 1.5963 & 33,25 \\
\hline 10 & $-0.25 \%$ & $2.84 \%$ & -1.1165 & 28,30 \\
\hline 11 & $0.22 \%$ & $3.06 \%$ & 0.9819 & 29,29 \\
\hline 12 & $1.06 \%$ & $4.12 \%$ & $* * * 4.7735$ & 16,42 \\
\hline 13 & $0.13 \%$ & $4.25 \%$ & 0.5747 & 28,30 \\
\hline 14 & $0.17 \%$ & $4.42 \%$ & 0.7548 & 25,33 \\
\hline 15 & $0.65 \%$ & $5.07 \%$ & ${ }^{* * \star} 2.9474$ & 26,32 \\
\hline
\end{tabular}

\begin{tabular}{|c|c|c|c|c|}
\hline 16 & $0.52 \%$ & $5.59 \%$ & $* * 2.3302$ & 31,27 \\
\hline 17 & $0.31 \%$ & $5.90 \%$ & 1.3933 & 29,29 \\
\hline 18 & $0.94 \%$ & $6.83 \%$ & ${ }^{* *} 4.2215$ & 23,35 \\
\hline 19 & $0.01 \%$ & $6.85 \%$ & 0.0647 & 25,33 \\
\hline 20 & $0.53 \%$ & $7.37 \%$ & $* \star 2.3731$ & 32,26 \\
\hline 21 & $-0.62 \%$ & $6.76 \%$ & $* * *-2.7739$ & 36,22 \\
\hline 22 & $0.75 \%$ & $7.50 \%$ & $* * 3.3593$ & 26,32 \\
\hline 23 & $0.06 \%$ & $7.56 \%$ & 0.2776 & 35,23 \\
\hline 24 & $0.61 \%$ & $8.18 \%$ & $* * 2.7507$ & 29,29 \\
\hline 25 & $0.02 \%$ & $8.19 \%$ & 0.0699 & 34,24 \\
\hline 26 & $0.48 \%$ & $8.67 \%$ & $* * 2.1420$ & 22,36 \\
\hline 27 & $-0.55 \%$ & $8.12 \%$ & $* *-2.4717$ & 32,26 \\
\hline 28 & $0.36 \%$ & $8.48 \%$ & 1.6284 & 30,28 \\
\hline 29 & $0.28 \%$ & $8.76 \%$ & 1.2463 & 31,27 \\
\hline 30 & $0.39 \%$ & $9.15 \%$ & $* 1.771257$ & 28,30 \\
\hline
\end{tabular}

* significant at $10 \%$ level Significant at $5 \%$ level ${ }^{* *}$ Significant at $1 \%$ level **

Table 7: Aggregate average abnormal returns (AAR) and t statistics of the overall sample on the IL announcement over the study period of 2007 to 2014.

returns from their regular relationship with the market over the periods adjoining the event day (from $-30^{\text {th }}$ day to $+30^{\text {th }}$ day). This scenario shows the cumulative effects of the residuals of all shares. Sometime AAR can be favors after the preceding the event-day if the market expects for goods news and adverse if the market anticipates bad news Table 7. T of AARs is mentioning the significance for the investigation period ( $\mathrm{t}=-30$ to +30$)$. In this table the number of events with favors and adverse abnormal returns in each day is précised under the column with sign of plus and minus.

The value of AARs which are a little fluctuating returns both favors and adverse associated to the IL announcement day. The aggregate average abnormal return (AAR) frequently negative prior to the impairment announcement date (event day $=0$ ). After the IL announcements are occurred the aggregate AAR is lower level than prior to the impairment losses are occurred. In the aggregate average abnormal returns fluctuate over the research period 2008-2014.

In the table, the values of CAARs are calculated by cumulated AARs continuously from day -30 to 30 . In the whole event window, the CAARs are negative (from day -26 to day+1) from the SP reflect to the IL announcement. During the event period the continuous downward movement of CAARs indicates that the market is guessing bad news from impairment. The increasing direction in CAARs can be perceived during the post period of IL announcement.

In addition, the Table 7 discovered that there was the possibility of the shareholders to lose the return on the market by impairment loss announcement. Evidence of CAAR during the $(-30,-1)$ period is $-1.31 \%$ supported by the facts which may be incurred due to possible leakage of information. CAAR for the $(0,+30)$ period is $5.8 \%$ due to the effect of information realized time on share price. Here investors show their under reaction of bad news. Consequently, this gentle reaction has the possible of producing abnormal returns based on the available information as publicly, which perform counter to the efficient market hypothesis. Lastly, it has been improved to $9.15 \%$ over the time of 61 days. Investors earned abnormal return at the end of event period, which supports to the inefficiency of the market [18].

The t-statistics show whether the aggregate AAR is significantly different from zero. Based on the outcomes the aggregate AAR on the IL announcement date (event day $=0$ ) is $-0.37 \%$, which is statistically significant at the $10 \%$ level. This indicates that the market absorbs the 
adverse signal very quickly, which released with the announcement of the IL writes down recorded by the entities. Hence, this indication recommends that the IL announcement day 0 deliver a stronger signal to the market than the other days.

As per the Table 7 shows that the 40 returns are positive and 21 returns are negative throughout the 61 days. Before the announcement of IL 15 returns are negative and on the event day and there after 05 returns are negative [19]. Before the 4 days of event day there is no negative AAR. The AARs are positive for $66 \%$ (40 days) and negative for $34 \%$ (21 days) during the 61 days of windows period. This implies that these returns are negative for a reasonable time. The above analysis indicates that the announcement information is disseminated before the event date. The situation of pre-announcement date shows more adverse sign than post announcement date is more strengthen the above fact.

The outcomes of the t-test present that the returns are significant for 29 days of event period including the 0 days. Significant at the level of $1 \%, 5 \%$ and $10 \%$ are 19 days, 7 days and 3 days respectively. The magnitude of the SP reaction of AAR on day 0 is negative in this research at the $10 \%$ level. +/- Sign shows that sample companies AAR is increased in negative value after the event date. It shows that while positive and negative remarks are fairly and evenly disseminated. By the way one significant aspect of the pattern of AAR prior to the declaration day can come from following sources: the IL announcement takes place often and is informed to the public proceeding to the declaration date that means information outflow. AAR prior to the declaration day reflects leakage of the insider information which are given by insiders and investors will access it and they expect the share price reaction toward negative.

Even impairment of non-current assets may be felt as bad information; it will lead to ensure the stability of firm value. Hence it will reflect the Cumulative Average Abnormal Return (CAAR) after the event date.

When inspects the Figure 1 it shows that how share prices reflect to the discharge of IL announcement. Market involvement expects that share price should be declined on the day in which adverse news has been declared. The value of AARs has shown the uneven yielding both positive and negative before and after the event day in the above graph and it discovered that the value of AARs has minor fluctuating yield and CAARs has a major fluctuating return. AAR $-0.37 \%$ and CAAR $-1.68 \%$ are produced on the event day. It is ensured that the market observes announcement of IL as adverse information about the forthcoming of the firm and CSE is developing a communication system as speedy, and this communication system enables an individual to access all accounting information and quick response to that news. This system may be created a heavy buying and selling pressure in the share market (Figure 2).

End of the research of the market reaction around the declarations of IL, we recommend to define the factors that explain this response by using the method of linear regression. Definitely, the announcement of IL is always conveyed by the announcement of financial information and other outcomes. In this situation, magnitude of market reaction can be affected by several other accounting and financial variables.

The trend in Figure 3 display the no big difference in volumes merchandised around the declaration date of impairment of assets written down. This probability has been occurred because the information of write down announcements is included in the trading of shares which was done in and around the event date. The standard
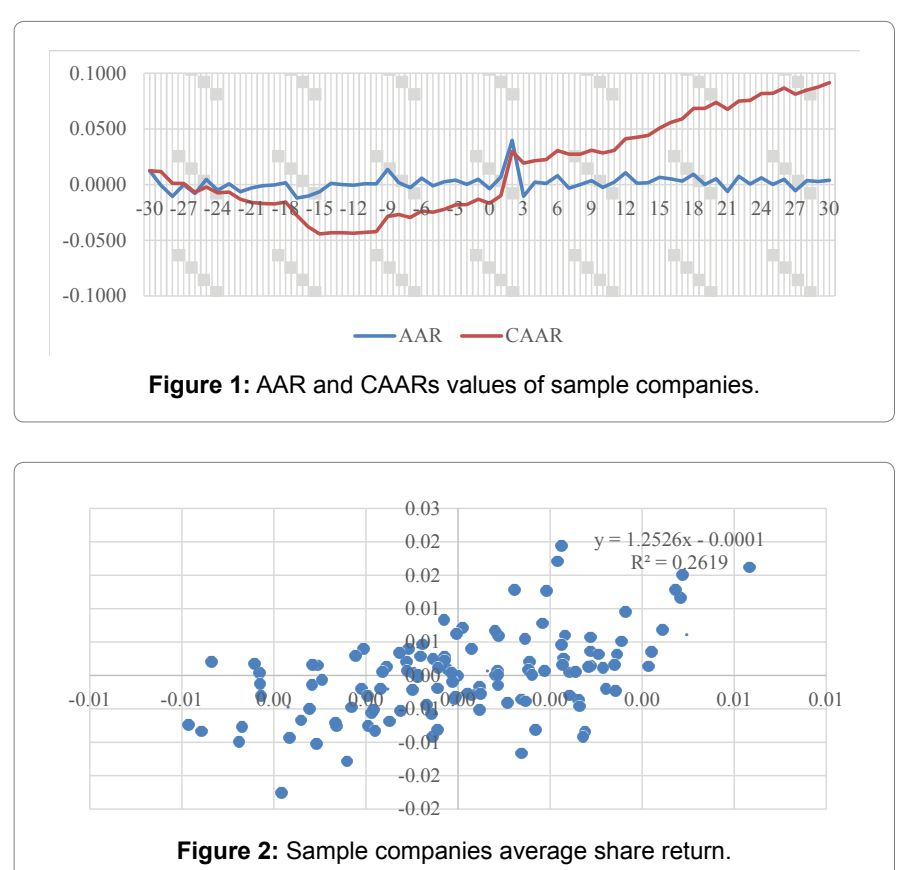

Figure 2: Sample companies average share return.

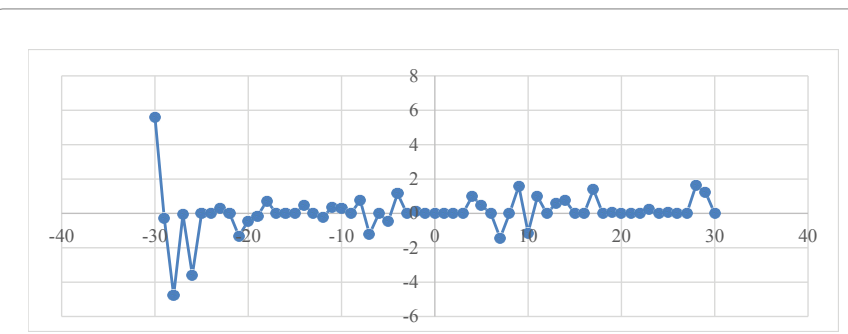

Figure 3: Graphical representation of tar for the 61 days event window.

deviation within that period was 0.6544 and average TAR before the event date was 2.1688 . The average TAR after the event date was 3.122488 while the standard deviation was 0.9422 which indicate that the variation in the TAR was very high. Since the difference in the TAR before and after the event date is significant, it indicates that the impairment writes down announcement did trigger a significant change on volumes traded during the event window. These results indicate that the CSE was not semi-strong efficient (Table 8).

The Cumulative Average Abnormal Return (CAAR) percent (\%) for the event period is in positive. The CAAR for $(-30,-1)$ is $-1.31 \%$. The CAAR for the period of $(0,+30)$ is $10.46 \%$. It indicates there is negative and positive reaction around impairment announcement. The CAAR for the period such as $(-5,+5),(-1,+1)$ and $(0,+1)$ are $4.62 \%, 0.80 \%$ and $0.32 \%$ respectively [20]. The negative response gets reduced on the post announcement days. There is also evidence for large negative abnormal returns prior to the impairment announcement [21-25].

\section{Findings}

In the above Table 9 shows the results of hypotheses test with related analysis tools.

Main Objective of this empirical research is to inspect the effect of impairment of non-current assets on share price. Researchers found the following results to detect the impact of impairment loss 


\begin{tabular}{|c|c|}
\hline Window & CARR\% \\
\hline$(-30,-1)$ & $-1.31 \%$ \\
\hline$(0,+30)$ & $10.46 \%$ \\
\hline$(-10,+10)$ & $7.13 \%$ \\
\hline$(-5,+5)$ & $4.62 \%$ \\
\hline$(-1,+1)$ & $0.80 \%$ \\
\hline$(-1,0)$ & $0.11 \%$ \\
\hline$(0,1)$ & $0.32 \%$ \\
\hline$(-30,30)$ & $9.15 \%$ \\
\hline
\end{tabular}

Table 8: Cumulative Average Abnormal Returns (CAAR) of Overall Sample.

\begin{tabular}{|c|c|c|c|c|c|}
\hline No. & Hypothesis & Tools & Sig & $\begin{array}{c}\text { Alternative } \\
\text { hypothesis }\end{array}$ & Conclusion \\
\hline H2 & $\begin{array}{c}\text { IL announcements } \\
\text { have significant } \\
\text { impacts on the SP. }\end{array}$ & Regression & $\begin{array}{c}\text { At level of } \\
10 \%\end{array}$ & $\begin{array}{c}0 \text { day t value } \\
\text { *-1.6682 (t) }\end{array}$ & Accepted \\
\hline $\mathrm{H}_{2}$ & $\begin{array}{c}\text { CSE is consistent } \\
\text { with the semi- } \\
\text { strong form } \\
\text { efficient market. }\end{array}$ & Event Study & $\begin{array}{c}\text { End of event period } \\
\text { CAAR shows the } \\
\text { positive return } \\
(-30,30) \text { CAAR }: 9.15 \%\end{array}$ & Rejected \\
\hline
\end{tabular}

Table 9: Results of hypotheses test.

announcements on share prices of the stocks trading on CSE. In this study, on the day of 0 , the greatness of the share price reaction of AAR is negative $[26,27]$. This is highly significant as statistically at the $10 \%$ level. Therefore, it revealed that IL announcement has significant impact on SP. As the announcement is one of the most important and periodic publicly available information. The analysis in this study has shown that the Colombo Stock Exchange is slow in reflecting this on the share price. The price adjustments are done continuously even after the event day and the excess abnormal return illustrates the share prices before the announcements and event day. Therefore, $\mathrm{H} 2$ is rejected since the market is not quickly responded to the price adjustments with publicly available information. It exhibits that lack of market learning is incorporated with value-changing information which is included in IL announcement [28].

Precisely, this study was commenced to discover the answers to the following research questions. First question is that do impairment loss announcements have impacts on SP of the stocks traded on CSE?

In order to support of this research question, the hypothesis was developed $\left(\mathrm{H}_{2}\right)$ and revealed that there is a significant impact of impairment loss on SP by $10 \%$ of $t$ value on the event day [29-31]. Final research question is that does the Colombo Stock Exchange (CSE) consistent with the semi-strong form efficient market? The analysis shows the significant abnormal returns have been earned by investors after the event day. Furthermore, in some cases there is evidence of leakage of impairment loss before the event day and that is why investors earn abnormal loss before the announcement of impairment loss of assets. Therefore, this study does not support the semi-strong form efficient market hypothesis. It is concluded that there is no existence of semi-strong market in Sri Lanka when IL signals on the stock prices.

\section{Conclusion}

Negative earnings surprises had a negative effect only on short term CAAR around announcements. We interpret this asymmetry as evidence that market efficiency is greater for negative earnings surprises (bad news) than for positive earnings surprises (good news). On the announcement date the experimental outcomes for impairment announcement showed a significant effect in Sri Lankan stock market. It was supported by the t-value. Also it was seen in two different opposite corner (positive and negative significant). T value of the announcement day was -1.6682; it indicated that IL significantly impacted on SP at the level of $10 \%$. It showed that market reacted adversely on the announcement date as significantly. Hence IL announcement impacted on SP adversely in CSE.

The conclusion is made that one explanation for the lack of reaction to announcement of IL is that the impairment was expected by investors due to poor economic conditions, and the reaction had been impounded in the stock price before the impairment was announced. Another possible explanation is that there were other events or indicators that caused a positive stock price reaction at the same time the companies made the announcement of the non-current asset impairment. It will lead to offsetting the negative reaction to the impairment. This study of individual stock fluctuations reveals that abnormal changes sometimes occur in periods surrounding IL announcements.

From the above outcomes, the research has revealed that Colombo Stock Exchange was not a semi-strong form efficient market. However, capital market efficiency not only depends on information such as historical price, public and private information but also on the implementation of the existing rules and regulations of the stock market and administrative efficiency of the same. Even the gradual adjustment of prices on the basis of available information recommends that the market was not informational efficient. The above findings exposed that IL announcements have the considerable effect on share price and the Sri Lankan share market shows the inefficiency for this announcement under the semi-strong from market efficiency.

Finally, share market movement in a country has been closely related with the stock market regulations and policies of the counties' economy. Sri Lanka can't except from this point. The terrorist attract, the political instability, the economic crises and continuing high rate of interest have had a negative impact on the performance of the CSE. Indubitably the tsunami which struck on December 2004 and 2008 civil war were the greatest disaster to have struck Sri Lanka. These events considered as triggering events for impairment test. The sudden and massive response to these events has given a new dimension to economic climate in the country. The time is opportune for us to look forward to the future. Consequently, the outcome of this study would be more favorable information and important than earlier studies in Sri Lanka to identify the market efficiency in the event of impairment of non-current assets announcement and to do the necessary action by the government and CSE to protect the investors and support to the economic growth of the country.

\section{Future Direction for the Study}

This research was initiated to do within the manufacturing companies. Forthcoming research could be drawn-out on this occurrence to other sectors or all sectors in the CSE, other research period, and test the other type of market efficiency.

\section{Limitations}

The limitations of the research are the technique chosen for this study is "hand-picking" the information from the financial statements, researchers collect the data for the above research from CSE and individual company's web sites from 2008-2014 and the data collection is dependent on the degree of disclosures in the financial statements and CSE data. Manufacturing sector only selected out of 20 sectors.

\section{Acknowledgment}

The academics would like to express their gratefulness to Higher Education for the Twenty-first Century for providing the grant (JFN/N5) to fund this research. 
Citation: Logeswary S, Thirunavukkarasu V (2019) Stock Market Reaction to Impairment Announcement of Listed Manufacturing Companies in Sri Lanka. J Account Mark 7: 307. doi: 10.4172/2168-9601.1000307

\section{References}

1. Company Act no 7 of 2007.

2. Colombo Stock Exchange (2014), Fact Book.

3. Keane SM (1986) The efficient market hypothesis on trial.

4. Fox A, Opong K (1999) The impact of board changes on shareholder wealth some UK evidence. Corporate Governance: An Int Review 7: 385-396.

5. Osei B (2003) How tied aid affects the cost of aid-funded projects in Ghana 30

6. Fama EF, Fisher L, Jensen MC, Roll R (1969) The adjustment of stock prices to new information. Int Economic Review 10: 1-21.

7. Ramesh S, Nimalathasan B (2008) Political Incidents of Sri Lanka and Their impact on the share prices: A study of listed companies in Colombo Stock Exchange (CSE between the periods of 2005-2008. International Conference on Competency Building Strategies in Business \& Technology: 528-543.

8. Hirschey M, Richardson VJ (2003) Investor under reaction to goodwill writeoffs. Financ Anal J 59: 75-84.

9. Strong JS, Meyer JR (1987) Asset writedowns: Managerial incentives and security returns. J Finance 42: 643-661.

10. Francis J, Hanna JD, Vincent $L$ (1996) Causes and effects of discretionary asset write-offs. J Account Res 34: 117-134.

11. Frantz $P$ (1999) Discretionary write-downs, write-offs, and other restructuring provisions: A signaling approach. Account Bus Res 29: 109-121.

12. Zucca LJ, Campbell DR (1992). A closer look at discretionary write downs of impaired assets. Accou Horizons 6: 30.

13. Elliott JA, Shaw WH (1988) Write-offs as accounting procedures to manage perceptions. J Account Res 26: 91-119.

14. Kvaal E (2005) Topics in accounting for impairment of fixed assets. Doctoral dissertation, Norwegian School of Management.

15. Ragothaman S, Bublitz BO (1996) An empirical analysis of the impact of asse writedown disclosures on stockholder wealth. Quarterly J Bus Economics 35 $32-47$.

16. Riedl EJ (2004) An examination of long-lived asset impairments. Accoun Review 79: 823-852.

17. Chen Y (2007) "Impairment of Assets recognized equity research to evaluate the impact of the electronics industry". Chung Yuan Christian University.
18. Ramesh S, Nimalathasan B (2012) Bonus issue announcements and its impact on share prices of Colombo stock. In Proceedings Int Conference Bus Manage 8.

19. Ramesh S, Rajumesh S (2015) Stock Market Reaction to Political Events: A Study of Listed Companies in Colombo Stock Exchange of Sri Lanka. Int Knowledge Sharing Platform 6.

20. Dissabandara DBPH, Perera KDI (2011) "The Impact of Dividend Announcements: Reconciliation Of Sri Lankan Evidence Over The Last Two Decades". Int Conference Bus Manag 8: 68-74.

21. Sooriyakumaran L, Thirunavukkarasu V (2013) Disclosures and impacts of impairment of non-current assets in the financial statements: A study on listed manufacturing companies in Colombo Stock Exchange (CSE) in Sri Lanka. Merit Res J Account, Auditing, Economics and Finance 1: 122-133.

22. Sooriyakumaran L, Thirunavukkarasu V (2016) Impairment of Assets and Market Value of Share: A Study of Listed Manufacturing Companies in Sri Lanka. Int J Account Bus Financ 2: 35-45.

23. Yang Z, Rohrbach K, Chen S (2005) The impact of standard setting on relevance and reliability of accounting information: lower of cost or market accounting reforms in China. J Int Financ Manag Account 16: 194-228.

24. Yuetang W, Xue Z, Li Z (2005) Write-down of long-term assets: The reflection of fair value or the action of earnings management? Account Res 8: 31-35.

25. Balachandran B, Faff $R$, Jong $L$ (2005) Announcements of bonus share options: Signalling of the quality of firms. Global Finan J 16: 180-190.

26. Li-Ling Yang, Tao-Sheng Chiu (2014) An Empirical Test of Stock Marke Reaction for Recognizing Assets Impairment: The Case of Taiwan. JIMS 9 : 75-86.

27. Logeswary S, Velnampy T (2014) Impact of Impairment Loss on Profitability and Capital Structure of Listed Manufacturing Companies in Sri Lanka. Int Conference Contemporary Management 1: 148-157.

28. Bandara D, Hareendra P, Samarakoon LP (2002) Dividend announcements, firm size and dividend growth in the Sri Lankan Stock Market. SLJM 7: 228-245.

29. Central Bank of Sri Lanka (2012) Equity market, Annual Report 210-212.

30. Hua SR (2013) A Study on Stock Split Announcements and its Impact on Stock Prices in Colombo Stock Exchange (CSE) of Sri Lanka. Global J Manag Bus Res 13: 26-34.

31. Chunguang Z (2006) Asset Impairments and Earnings Management. J Account Res 3. 